Article

\title{
Lost in Transition? Directions for an Economic Geography of Urban Sustainability Transitions
}

\author{
Sebastian Fastenrath $1,2, *$ (i) and Boris Braun 2 (1) \\ 1 Melbourne Sustainable Society Institute, University of Melbourne, Parkville, VIC 3010, Australia \\ 2 Institute of Geography, University of Cologne, 50923 Cologne, Germany; boris.braun@uni-koeln.de \\ * Correspondence: sebastian.fastenrath@unimelb.edu.au; Tel.: +61-3-8344-4537
}

Received: 19 April 2018; Accepted: 7 July 2018; Published: 12 July 2018

\begin{abstract}
Socio-technical transitions towards more sustainable modes of production and consumption are receiving increasing attention in the academic world and also from political and economic decision-makers. There is increasing demand for resource-efficient technologies and institutional innovations, particularly at the city level. However, it is widely unclear how processes of change evolve and develop and how they are embedded in different socio-spatial contexts. While numerous scholars have contributed to the vibrant research field around sustainability transitions, the geographical expertise largely has been ignored. The lack of knowledge about the role of spatial contexts, learning processes, and the co-evolution of technological, economical, and socio-political processes has been prominently addressed. Bridging approaches from Transition Studies and perspectives of Economic Geography, the paper presents conceptual ideas for an evolutionary and relational understanding of urban sustainability transitions. The paper introduces new perspectives on sustainability transitions towards a better understanding of socio-spatial contexts.
\end{abstract}

Keywords: sustainability transitions; economic geography; urban innovation

\section{Introduction}

Socio-technical change in the sustainability context is increasingly receiving attention from a wide range of academic disciplines but also from public and private sectors. Cleaner and resource-efficient technologies and practices are required in contexts such as energy, transport, waste recycling, green space, agriculture, housing, and construction. Within the debates about alternative modes of production and consumption, cities are understood as the key arenas for socio-technical change [1-4]. However, how sustainability transitions occur and develop, and how they are interrelated to economic and socio-political processes, is widely unclear [5,6]. A number of questions need to be answered to further understand spatiality and temporality in sustainability transitions: When, where, why, and how do transitions happen? Why are there forerunner places with significant shifts towards new socio-technical structures while other places lag behind? What are the conditions and pathways that lead to change or resistance? What or who are the drivers and detractors?

New analytical perspectives and conceptual approaches are required to gain further knowledge about how the dynamics of sustainability transitions are embedded in specific spatiotemporal contexts [7]. A special focus needs to be drawn on the dynamic interplay of changed practices, institutional processes, and related driving and hindering actors. It is surprising that geographical concepts largely have been neglected in transition research, even though the lack of socio-spatial contextualization has been acknowledged by a number of scholars [8-11]. The introduction of ideas for a 'Geography of Sustainability Transitions' $[7,11-13]$ was an important first step towards an analysis of the contextualization of transitions. These articulated theoretical thoughts outlined a geographical 
research agenda beyond the vibrantly used heuristic framework of the 'Multi-level Perspective' (MLP) in Transition Studies [14].

This paper aims to develop conceptual ideas considering economic geographic perspectives to overcome the "[ ... ] naïve conceptualization of space, scale and power" [13] (p. 15) in sustainability transition research. As various scholars suggest, combining approaches from Economic Geography and Transition Studies (TS) helps to understand and analyse socio-technical change and its embeddedness in socio-spatial structures (e.g., $[5,13,15,16])$. Both heterogeneous research fields share a common understanding of path dependencies, thinking of continuity of change, and the influence of institutional contexts.

Economic Geography concepts with an evolutionary and relational understanding of economic development (e.g., [17]) are most suitable to link these concepts. Nevertheless, these approaches need a more practice- and institutional oriented research focus in the sustainability transitions context. Jones and Murphy [18] (p. 371) argue that the focus on practices can "provide a grounded theoretical lens for understanding how a diverse range of processes and phenomena (e.g., learning, networks, governance, development, livelihood strategies) occur, evolve, and/or become transformed over time and in space". Moreover, a growing number of contributions emphasize the important role of actors and actor networks, grassroots movements, and policy-makers as key drivers behind sustainability transition. Truffer and Coenen [13] (p. 15) refer to examples showing that "cities and regions can become powerful promoters of sustainability transitions when understood as relationally embedded actors and providing crucial resources for successful innovation processes". During the last few years, scholars have demonstrated empirical research on how pioneering innovative socio-economic practices are driving environmental technologies [19-21].

The aim of this contribution is to shed light on urban sustainability transitions by bringing together approaches from Transition Studies and Economic Geography. In Section 2, the paper traces the common grounds of both research fields in understanding and exploring socio-technical change before the paper will explore the distinctive nature of sustainability transitions. Economic Geography perspectives in the context of investigating sustainability transitions are discussed in Section 2.1. In Section 3, the paper presents conceptual ideas for analysing changed practices and related drivers and processes in urban sustainability transition processes. Section 4 provides concluding thoughts.

\section{From Evolutionary Economics to a Geography of Sustainability Transitions}

For more than two decades, research on socio-technical transitions has been conducted in the field of social study of technology (SST), better known as Transition Studies. This popular multi-disciplinary research field has brought together insights from economics, innovation, and technology studies, history, and social and political sciences. Scholars of Transition Studies particularly focus on a systemic understanding of technological change as a co-evolution of technologies but also of policies, user patterns, infrastructures, and cultural discourses [10]. Similar to approaches of 'Evolutionary Economic Geography' and 'Geographies of Innovation', the roots and central conceptual ideas go back to Evolutionary Economics [22-24]. Evolutionary Economics emerged as an alternative conceptual idea to the static neoclassical, orthodox concepts of economic and technological change. The main goal of scholars at that time was to develop an "[ ... ] evolutionary viewpoint as a possible framework for a more realistic economic theory of firm and industry behaviour" [23] (p. vii). Evolutionary Economists started to develop a more precise understanding of technological change and interrelated processes and mechanisms by which economies develop. A key idea was to trace past economic and other related processes to better understand current economic dynamics-in other words, 'history matters'. Similarly, the Economic Geographers Lloyd and Dicken stated that "the economic landscape is the cumulative expression of decisions made at different points in time and under a variety of conditions" [25] (p. 238).

Nelson and Winter [23] introduced a new thinking about the drivers of innovation, technological change and decision-making processes. The authors explicitly responded to the lack of institutional 
and political considerations in economic research at that time. They argued that informal institutions, actors (single and groups), and policies are crucial factors for economic development. Moreover, they stated that "public law, policies, and organizations are an important part of the environment that shapes the evolution of private sector activities" [23] (p. 371). Based on a case study from the United States, Nelson and Winter explained their conclusions. By tracing back air quality regulations on different policy levels and interrelated changed economic practices from the 1950s to the 1970s, they emphasized the interactions between industry actors, policies and public administration. Reviewing this case study, Nelson and Winter stated that public policies also tend to follow certain trajectories. They argued that "policy changes today might fruitfully be understood as evolving from a policy base that was itself the outcome of a sequence of earlier changes, and, in turn, as setting the stages for future evolutionary developments" [23] (p. 376). Since then, the understanding of economic development has been based on the assumption that economic action is embedded in institutional and social structures $[26,27]$. Concepts and empirical research of systems of innovation and technological change occurred [28-30]. Scholars started to examine the interrelations and co-evolution between technological trajectories and institutional coordination.

The heterogeneous field of 'Transition Studies' occurred with a more technological focus [14,31-33]. Transitions are understood as socio-technical changes resulting in technological change that is socially embedded and follow certain pathways. Theoretical ideas are based on the premise that technological change is the result of the interactions of co-evolutionary and non-linear processes between a wide range of economic, socio-cultural, political, and institutional spheres [10,32]. New products, services, business models, organisations completely or partly substitute existing ones [34]. These interrelations are demonstrated in a number of historical and more recent examples such as shifts from sailing to steaming ship [14], from horse-drawn carriage to automobiles [35], or from cesspool to sewer systems [36]. However, space and location have not been considered explicitly in the theoretical and empirical approaches in Transition Studies.

\section{Sustainability Transitions}

Since the 2000s, publications in Transition Studies are increasingly focused on socio-technological change in the environmental and sustainability context [37-39]. While there are various understandings, Markard et al. [40] (p. 955) define sustainability transitions as "transformations towards more sustainable modes of production and consumption". The goal of scholars in this research context is to understand shifts in the heterogeneous field known under different terms such as eco-innovations, green-, environment-, or clean technologies [34,40-42]. Socio-technical processes have been addressed in a wide range of research areas such as renewable energy, agriculture, transport, waste recycling, water supply, and building and construction.

The major difference of sustainability transitions compared to conventional socio-technical transitions is the strong influence by a number of political, scientific, and civil societal actors [34]. Sustainability transitions are not solely economic or technology driven; they must be interpreted as the result of incremental socio-spatial dynamics influenced by normative expectations [34,43]. Cooke [44] identified a 'green turn' in innovation systems which is strongly driven by policies and societal powers. Policies (regulations, guidelines, incentives) are identified as important drivers for sustainability transitions. Also, Truffer and Coenen [13] (p. 12) argued that "sustainability transitions are by their very nature political projects". Therefore, innovative technologies and practices are increasingly understood and conceptualized as niche developments in 'protective spaces' where pioneers can experiment and learn under policy and societal protection [45].

Transitions in the sustainability context are progressively understood as highly embedded processes in specific socio-spatial contexts of places, regions, or cities [11]. Urban case studies demonstrate how context-specific pathways of institutions, economic practices, political mechanisms, and driving and hindering actors influence the dynamics of sustainability transitions [21]. New technologies, lifestyles, economic practices, or policies can occur as a result of these processes [11]. 


\section{The Multi-level Perspective}

The most recognised concept and theoretical idea to explore phenomena in the field of socio-technological change is the Multi-level Perspective (MLP) (e.g., [14,41]) (see Figure 1). The MLP "provides an overall view of the multi-dimensional complexity of changes in socio-technical systems" [46] (p. 495). This heuristic framework was established to develop an understanding of long-term transition processes by explaining key processes and drivers behind socio-technical change. In the MLP, understanding transitions happens as a result of co-evolutionary interactions between three analytical levels [14]: (1) A niche level, where innovations occur and build up momentum; (2) a socio-technical regime level where established structures and networks of actors, institutions and economic practices become stabilised over time; and (3) a landscape level, the wider context where large influencing factors such as global discourses occur.

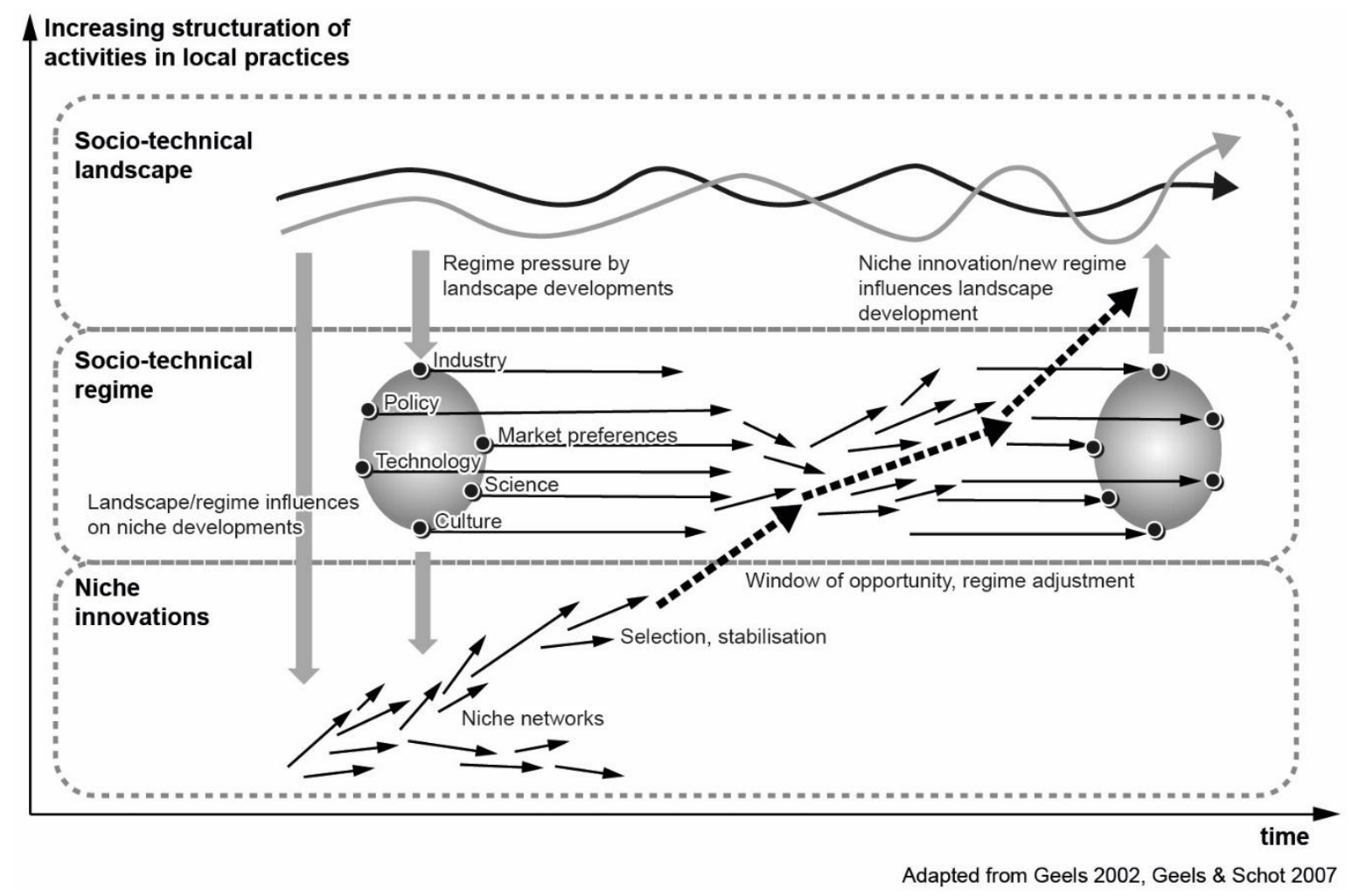

Figure 1. The Multi-level Perspective.

The most important level in the MLP framework is the niche level. Geels explains niches as 'protected spaces' where (radical) innovations, pioneer projects, and learning processes occur. These can result in new, stable socio-technical configurations at the regime level when powerful actors and networks accept these niche developments. The regime concept is understood as an interpretive analytical concept. While the analytical concept of the socio-technical system "refers to tangible and measurable elements" [14] (p. 473) (e.g., market shares, regulations, consumption patterns), the regime is understood as a more intangible analytical entity. The socio-technical regime refers to the rules and routines in which actors are embedded and on which draw concrete actions.

However, as Smith et al. [42] (p. 436) argued, "this attractive big picture is not without its challenges". A general critical debate about the MLP framework occurred for a number of reasons [43]. A core critique is the fuzzy heuristic and interpretative character and, therefore, empirical limitations. Apart from that, a general debate exists on epistemological aspects and the challenges in 
operationalizing concrete research objectives [16,42,43,47-49]; a number of those aspects are related to the sustainability context.

The dominant 'technocratic' understanding of innovation and of the niche-driven directions have been critically discussed [13,41,42]. There is growing evidence that the normative character and the strong public interest in sustainability issues strongly leads to different logics of socio-technological and economic change. Thus, there is a need for a closer look at established policy and economic structures as drivers for change but also as resisting detractors. While most studies explore successful green niche innovations, processes and actors at the regime level have been neglected. Concepts to operationalize regime-niche interactions are required to identify drivers, policy structures, and power constellations $[39,50]$. Therefore, it is crucial to gain knowledge about successful but also failed or distracted sustainability transitions. Institutional and economic path dependencies, interest structures, driving and hindering actors need to be identified. The dynamics and interactions within the regime but also between niche and regime require more scientific attention. This knowledge is critical to provide recommendations for policy-makers and industry actors [51].

Scholars agree that exploring the socio-spatial and temporal contextualisation can help to better understand these interrelations [10,12]. However, concepts in Transition Studies that offer a distinctive spatial perspective are still lacking. Perspectives of Economic Geography are predestined to add knowledge to how technological innovations, changed economic practices, and processes are embedded in social, political, and wider economic structures at different times [52].

Bringing together viewpoints from Evolutionary Economic Geography (e.g., [53]), Geography of Innovation (e.g., [54]), and Environmental Economic Geography (e.g., [55-58]) is valuable for developing new theoretical and conceptual approaches for sustainability-oriented transition research. We agree with Murphy who stated that the geographical perspective helps to "understand the development trajectories of cities, industries, production networks, and economies" [7] (p. 73).

\subsection{Economic Geography Perspectives on Socio-Technological Change and Sustainability}

Since the 1990s, Economic Geographers and scholars from related disciplines enrich the debates on technological change with socio-spatial and evolutionary aspects [59-62]. These scholars developed a more socio-spatial understanding of economic development and, therefore, can be seen as the originators of an "evolutionary school of technological change" [63] (p. 571). Considering a relational and evolutionary approach of technological change, researchers explore path dependencies and learning processes within economic structures, predominantly in industrial production systems at the firm level [64-66]. Concepts such as 'innovative milieus' [67] and 'clusters' [68] highlight the role of spatial contexts in innovation processes. In Economic Geography, institutions are increasingly understood as "central to the socio-cultural construction of the economic" [69] (p. 77). The proximity of actors, embedded learning processes and institutional interactions have been identified as important drivers for innovation [70].

Many scholars agree that technological innovations are influenced by interactions within innovation systems [71]. Technological change and the interplay with institutions and organisational structures have been explored for systems at different spatial scales. Apart from 'national innovation systems' [72], the concept of 'regional innovation systems' particularly has been conceptualized and empirically analysed [73-78]. Regional innovation systems are understood as "economic and social interactions between agents, spanning the public and private sectors to engender and diffuse innovation within regions embedded in wider national and global systems" [76] (p. 878).

Synchronously, scholars within the broader field of 'Environmental Economic Geography' (EEG) contributed to the debate around technological innovations, environmental protection, institutions and knowledge creation [57,58,79-90]. Conceptual and empirical approaches in EEG highlighted the important role of non-economic actors and drivers of 'greening' processes of firms, production networks, and industry sectors. The special context of green, eco, environmental or sustainability 
innovations and the contextual interplay of regulation and industrial-environmental processes towards sustainability actions have been explored.

Hayter and Le Heron [89] argued that 'green-facilitative institutions' are likely to have different spatialities and temporalities compared to established institutions. The authors predicted a "transition from narrow economic and profit oriented technological focus to one that resolutely incorporates green dimensions in technological change" [89] (p. 401). However, socio-political perspectives and the interplay of economic and institutional processes in eco-innovation research are still missing and have been continually articulated $[5,6,21,42,91]$. The important role of EEG in sustainable development research and as an important emerging field in Economic Geography was emphasised by Aoyama et al. [92].

Parallel to these ideas towards an Environmental Economic Geography, thoughts for an Evolutionary Economic Geography dominated the debates about spatial contextual aspects of technological change [57]. The key concepts within this evolutionary approach, including 'path creation' [93,94], 'path dependence' [95-97], 'lock-in' [98-101], and 'path plasticity' [102], help to understand interactions between economic, technological, and institutional developments. Similar to approaches from Transition Studies, Evolutionary Economic Geography has a co-evolutionary understanding of technologies, institutions and the dynamics of socio-technical change. The core understanding of most of these conceptual approaches is that economic evolution is based on ongoing processes and the "never-ending interplay of path dependence, path creation and path destruction that occurs as actors in different arenas reproduce, mindfully deviate from, and transform existing socio-economic-technological structures, socio-economic practices and development paths" [103] (p. 408). Bringing together these ideas, Simmie [94] conceived an improved conceptual framework to explain socio-technical change, based on previous work on path creations $[93,104]$ (see Figure 2).

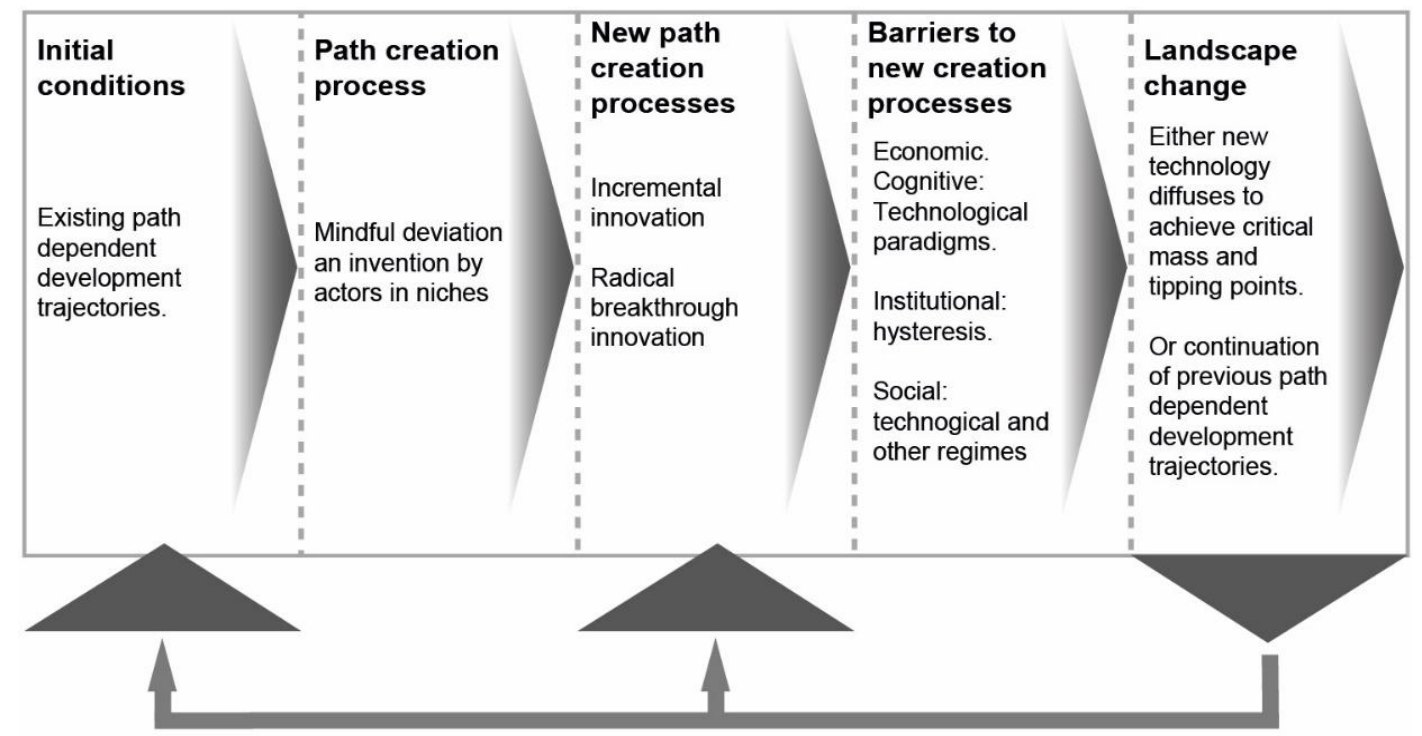

Figure 2. Path creation theory (adapted from Simmie [94]).

The framework's core ideas of path creation help to conceptualize different processes and phases within sustainability transition pathways. However, new empirical perspectives are needed to understand in more detail the drivers and disruptions in sustainability transition pathways. In particular, it appears necessary to investigate how economic and institutional pathways are interwoven. Bridging ideas from Transition Studies and the three streams of Economic Geography is valuable for further sustainability transition research. There is a need to shift research from a dominant technological focus to a broader understanding of innovations which also include institutional and social innovations. The criticized firm- and technology-centred perspectives of innovation which are 
still often applied in research (e.g., [105]) have to be transformed to a more evolutionary practice- and policy-oriented perspective. Innovation policies and power constellations are increasingly evaluated as important drivers for transformational change in the sustainability context $[4,5,50]$. Researchers particularly need to focus on policy regulations and public planning mechanisms, such as urban infrastructures (water, energy, waste, transport) and building and construction.

\section{Towards an Economic Geography of Urban Sustainability Transitions}

Cities and city regions have been identified as important seedbeds and experimental arenas for sustainability transitions $[2-4,106]$. These discussions culminate with the transdisciplinary debate on climate change, resource efficiency, resilience, and energy transitions. Public administrations, NGOs, researchers, and practitioners are looking for technological, political, and organisational solutions to more sustainable modes of production and consumption.

However, research approaches for urban sustainability transitions are lacking. Indeed, theoretical and empirical research at the city level is challenging. Cities are embedded in wider complex political, economic, and social systems at different scales, and every city is an irreducible individual case [107]. To overcome these challenges is a major task for Geography and its sub-disciplines. Geography of Sustainability Transitions provides approaches to explain socio-spatial dynamics, power relations, and political aspects to the geographical research agenda [7,11,12]. Murphy [7] (p. 75) highlighted the special role of spatial contexts in which transitions are embedded: "[T]ransitions are shaped both by the ways in which socio-technical systems are embedded in particular territorial contexts, and by the multi-scalar relationships linking their heterogeneous elements to actors, materials, and forces situated or emanating from different locations or scales".

There is a growing number of publications exploring place specificity in sustainability transition processes. One group of scholars highlights the role of multi-scalar and trans-local aspects and exogenous forces in sustainability transitions (e.g., [8,108,109]). Apart from the discussion of spatial transferability of technological aspects, including adaptation processes from one place to another, changed practices, and single learning processes, scholars have presented ideas for 'policy mobility' [110-113]. The core idea behind these approaches is that, similarly to technologies and business models, policies and other institutional settings can also be adopted and reconfigured to other places. Other scholars emphasise the need for further considerations of endogenous processes at the city level and how exogenous factors have an impact on local processes, especially as urban sustainability transitions receive further attention $[21,106,114,115]$.

Nevertheless, most of these research approaches aim to explore innovations (technological or institutional) and its socio-spatial relations. Drawing on these conceptual considerations as well as empirical insights into urban case studies on 'green building' transitions in Freiburg (Germany) [21] and Brisbane (Australia) [116], we suggest new ideas to conceptualise and analyse urban transitions processes. Without neglecting the exogenous influences on urban transitions, it is crucial to analyse the endogenous characteristics such as local policies (regulation, incentives, and guidelines), local learning processes, and actors (driving and hindering/disrupting). In particular, identifying local and trans-local drivers and barriers is valuable to gain more knowledge on transition processes. We argue that agency and power, learning by doing/using, successful and disrupted transition processes and actors at different times in the past have an impact on developments in the present. This understanding of sustainability transitions should help researchers and also actors from the public and private sector support and steer sustainability transition dynamics. The in-depth knowledge of specific city contexts and its structures and developments is crucial to generate support by measures such as new policies, incentives, changed business models, or industry practices.

Bringing together ideas of the Multi-level Perspective and the different strands of Economic Geography can help to conceptualise the dynamic socio-spatial processes of sustainability transitions at the city level. Moving forward from these ideas, we suggest a new conceptual framework that understands sustainability transitions as changed practices in the broader socio-spatial context, 
including the interplay and outcome of political-institutional and economic and socio-cultural structures (see Figure 3). Within this framework, three analytical entities and their reciprocal interactions for urban sustainability transition research are suggested:

1. Pathways (technological and political-institutional).

2. Changing practices, processes of learning, and hindrance.

3. Actors/actor networks (private, public, individual, collective).

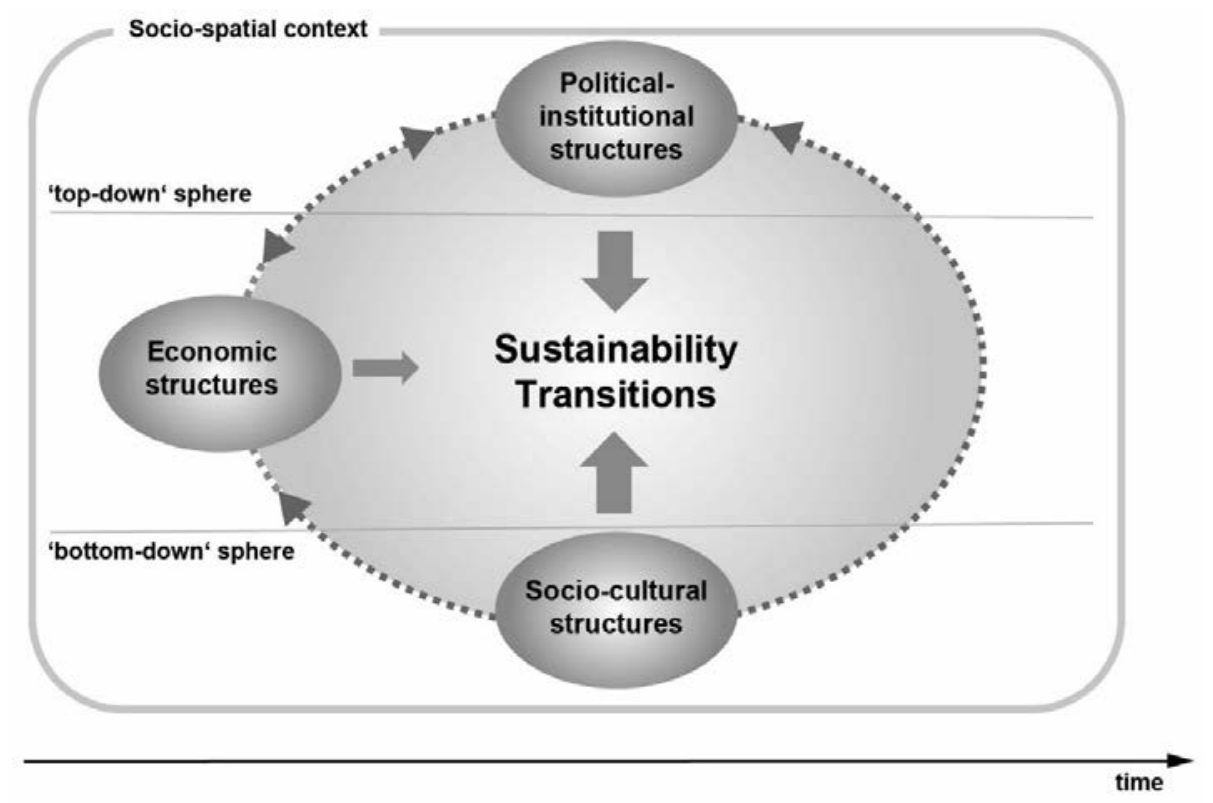

Figure 3. Sustainability Transitions dynamics (own figure).

\section{Pathways-Understanding the 'urban transition history'}

As an important step towards a broader understanding and analysis of urban sustainability transitions, we suggest an analysis of pre-existing structures within sustainability transition pathways $[13,117,118]$. Socio-technical transition processes usually happen over several decades. Changes in the sustainability context may occur faster. Considering the distinctive normative nature of sustainability transitions, the speed and the directions of change are often explained by society-driven 'bottom-up' or/and policy-driven 'top-down' activities. Geels [50] suggested that policy-making processes especially need a closer examination in their function as drivers or detractors of sustainability transitions. Therefore, the MLP understanding of niches as the most important level and generally as seedbed of technological innovation seems to be increasingly unsuitable for sustainability transition research.

We argue that socio-technological processes in urban settings follow context-specific logics and pathways, driven by the interplay of political-institutional, economic, and socio-cultural structures. Sustainability transition pathways are non-linear and incremental developments; they are the result of negotiations, agency, adoption of technologies, and practices. Place-specific economic and political logics can drive or hinder processes of change $[21,116]$. There is an increasing understanding that changes towards sustainability are often driven by institutional 'niches' and the interplay with context-specific actors. As Coutard and Rutherford [119] highlighted, there is a lack of research on the outcomes of policies in urban transition contexts. During the last few years, new institutional understandings were introduced and explored. For instance, Nightingale [120] discussed the struggles of power and politics and actors on different levels in local climate change adaptation. Also, interdisciplinary approaches such as 'evolutionary governance theory' [121] appear promising for further interdisciplinary transition research. 
To understand how economic and policy trajectories are interlinked and drive or hinder transitions in urban contexts is a major task in transition research. Therefore, the analysis of different context-specific pathways of technological change in relation to institutional changes is crucial for an in-depth understanding of socio-technical change. Tracing back and exploring the dynamics, directions, and interactions towards changed practices and routines in sustainability transitions context is a major challenge. First examples of urban case studies demonstrate the value of tracing back sustainability pathways. Burch [122] provided insight into policy pathways (initiatives and regulation) and their outcomes on different sustainability areas in Vancouver. Fastenrath and Braun [21,116] explored the interplay of policy pathways and changed practices in building and construction towards 'greener' outcomes in the city of Freiburg, Germany and Brisbane, Australia.

Thus, we propose a stronger focus on interactions between technological use and adoption, and the outcome of learning processes in niches and in "business-as-usual regimes" [7] (p. 88). There is the need to look more closely at policy action and guidance, and the dynamics of economic change and power within established political-institutional and economic structures $[7,45,50,123,124]$.

\section{Changed practices-understanding learning processes and resistance}

To understand couplings, directions, and the dynamics of sustainability, research needs to focus on how changing practices (technological, institutional) and learning processes are embedded in city contexts [125,126]. As Geels [50] suggested, innovation processes and related 'learning by doing' and 'learning by using' needs to be scrutinized. Studies have demonstrated how changed practices and localized learning can be crucial for sustainability transition pathways on the local level [20,125,127-129]. Pioneer projects are seen as important triggers for 'preadaption' [108] and as 'stepping-stones between niche and mainstream' [38]. Knowledge generation, spillovers, and specialised skills can be the result of policy action towards sustainability transitions. Apart from these 'bottom-up'-directed changes, there is also evidence that 'top-down'-directed local policies and regulation can evoke changed practices and create learning processes [21].

An in-depth analysis of processes of change and transformation, and also of detractions, resistance and lock-in against sustainability-oriented shifts, is important to further understand the role of established structures [48,50,129-131]. There is a lack of knowledge about processes when actors form a "core alliance at the regime level, oriented towards maintaining the status quo" [50] (p. 6). Therefore, a changed focus is needed from how 'green' niches occur and develop towards a perspective of how established economic and political structures support but also hinder sustainability transitions (see Figure 4).

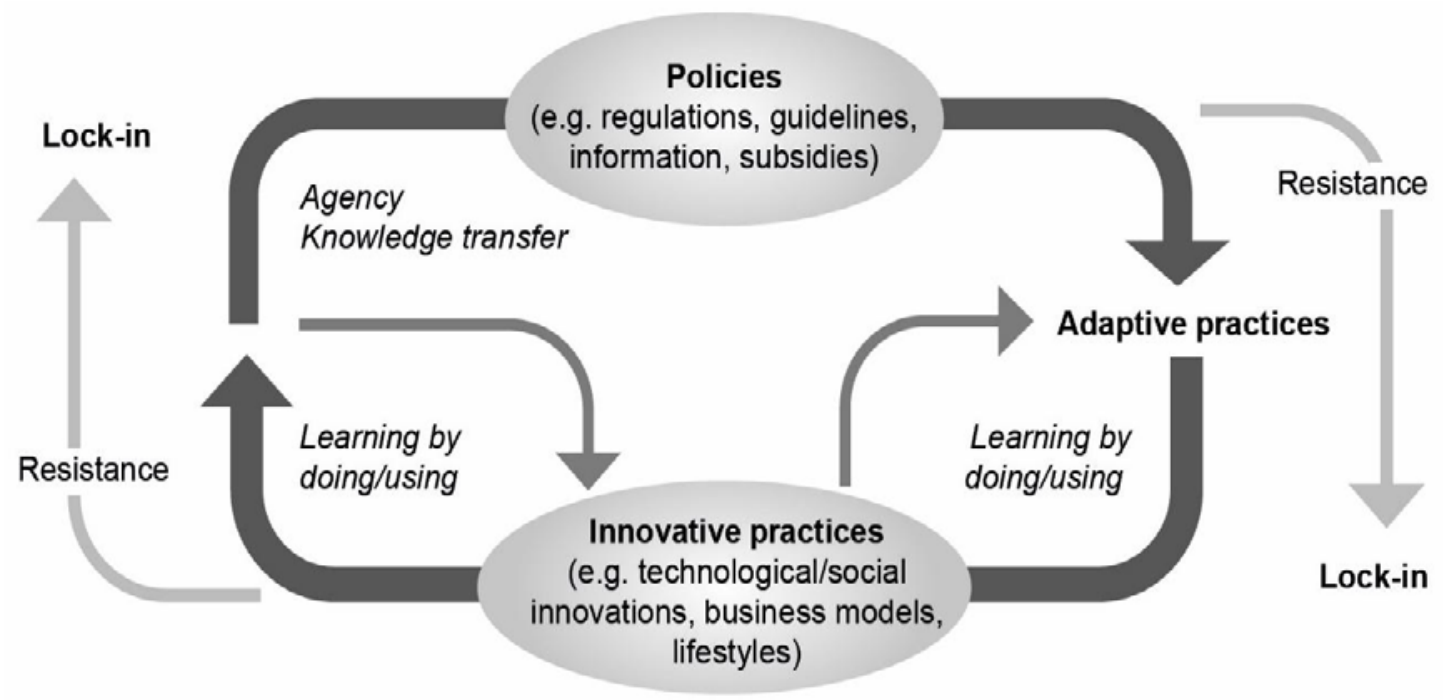

Figure 4. Practice change in sustainability transitions (own figure). 
It is essential that we identify learning processes as well as mechanisms of 'regime resistance' [50], lock-in [48], and inconsistencies [122] within sustainability pathways. Particularly crucial for a better understanding of urban sustainability contexts is the role of policy action and the reciprocal interactions with learning processes, technological innovations and changed practices. Therefore, we need contrasting urban case studies to provide explanations for successful and unsuccessful transition processes.

\section{Actors-understanding the drivers and their interests}

The heterogeneous field of actors in urban sustainability transitions is receiving more attention. Understanding the interplay of actors from public, private, and academic sectors is a key analytic object in transition research (see Figure 5). It is widely accepted that actors (individual and collective) play an important role when interacting with economic structures and also with the political and institutional context in innovation processes. Actors in city contexts can play a key role as catalysts for new practices, technologies and new narratives [132]. Thus, there is an increasing number of publications focusing on actors and actor networks in urban sustainability transitions $[1,91,106]$.

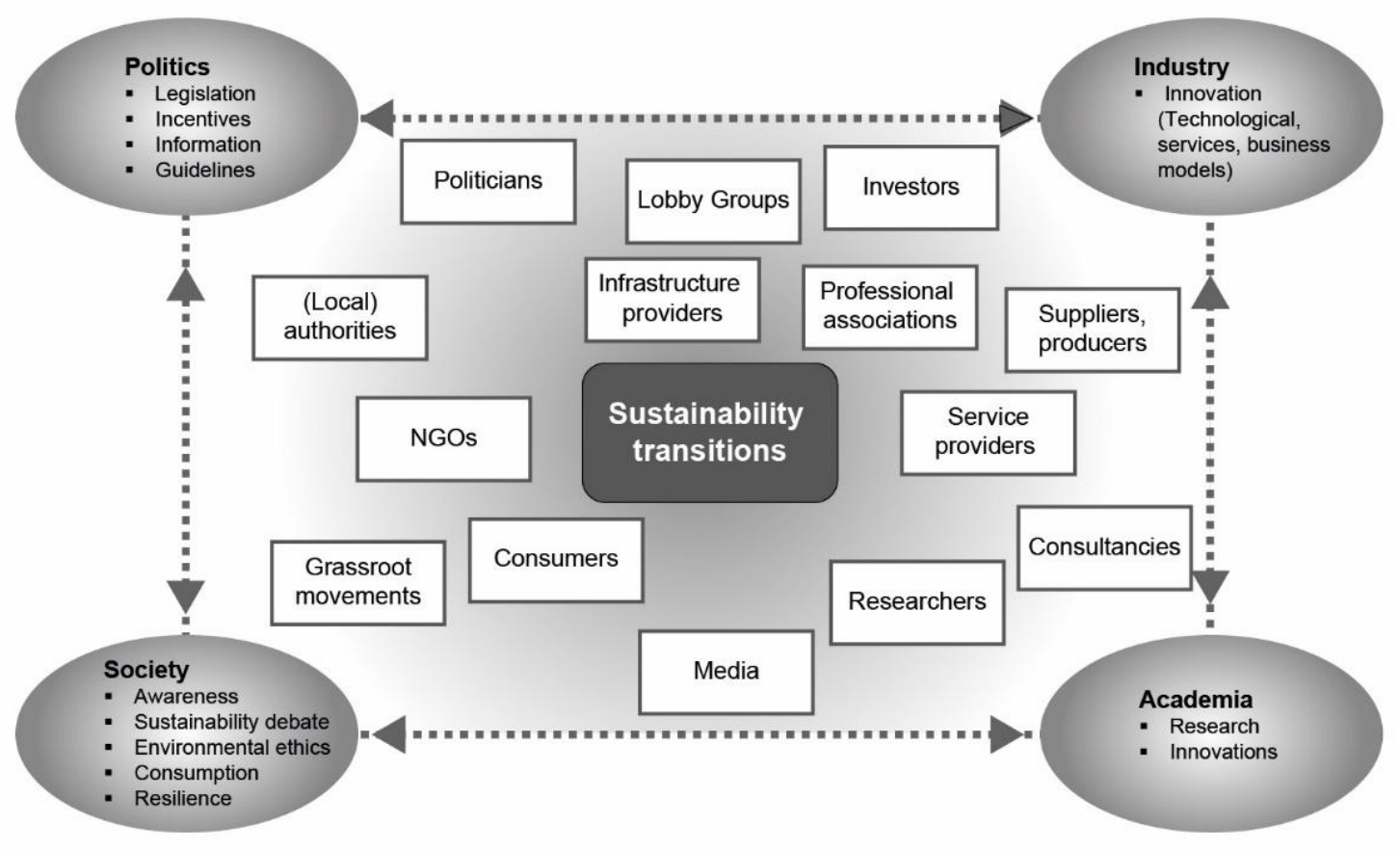

Figure 5. Key actors in urban sustainability transitions (own figure, adapted from Schulz 2002).

Studies have demonstrated how local actors, such as city governments and its various city authorities (e.g., planning, transport, environment/sustainability, building and construction, disaster management), are able to drive 'top-down' socio-technical change through formal and informal institutions [21,122]. In many countries, mechanisms of 'local self-government' allow city governments leeway to develop innovative local policy initiatives, adapt ideas from other urban contexts, and support experimental projects.

On the other side, 'bottom-up' actors such as single pioneers or collectively organised grassroots movements have been identified as crucial drivers in urban transition processes [133]. They can create knowledge through adoption of innovative socio-technical practices, 'niche experimentations' [134] and learning by doing/using [2]. Case studies have demonstrated that 'bottom-up' actors can be crucial by addressing interests, ideas and knowledge through agency as "transition agents" [21]. Fastenrath and Braun identified that significant changes occurred when actors such as single pioneers, networks, or environmental citizen movements are able to interact with established political and 
economic structures. Another key finding was that the directions of urban transition processes can change over time. While an initial 'bottom-up' path could be identified, what occurred later in the process was a dominant 'top-down' path driven by politicians and city authorities.

Nevertheless, sustainability transition processes are not always success stories. There is a lack of research focusing on "transition detractors", actors which hinder or distract transition processes. For instance, an opportunity for further research is to look more closely at lobby groups and their interests as well as the interventions of political parties or public administrations. How and why successful sustainability strategies and "blocking-mechanisms" [7] (p. 88) occur and are embedded in the socio-spatial context needs to be highlighted in further transition research.

\section{Conclusions}

This paper introduced new perspectives on urban sustainability transitions. Our key goal was to provide alternatives which go beyond the prominent concept of the 'Multi-level Perspective' introduced by scholars of transition studies [14]. This theoretical approach has been criticized for its vague conceptual framework, operationalisation challenges, and strong interpretative character [42]. Moreover, the concept does not provide answers, as to why and how transitions occur and develop unevenly in different spatial contexts. A geographical turn is required to overcome the inadequate conceptualisation of space in transition research to better understand socio-economic processes. Based on the introduced and much-noticed research agenda of a 'geography of sustainability transitions' $[7,12,13]$, this paper sheds light on possible directions for new research on socio-technical change.

In this paper, we traced the common grounds and differences of Transition Studies and Economic Geography approaches which focus on socio-economic change. Since Nelson and Winter [23] introduced ideas for a new understanding of temporality and drivers of economic processes, research on socio-technical processes has continually changed. In various scientific disciplines, the crucial role of actors, networks, and institutions has been identified as an important force for economic and technological change. To cope with sustainability transitions, we argued that new concepts are required. The strong normative character of sustainability and its societal recognition leads to new processes of economic and technological changes. Changed economic and social practices towards more sustainable modes of production and consumption are often influenced by societal and political factors. These factors are highly variable in space and time and need stronger consideration. Thus, the understanding of innovations needs to change from a technocratic to a broader understanding of changed economic practices that also consider socio-cultural and institutional elements.

Over the last few years, a number of contributions have demonstrated that eco-/environmental innovations occur in the context of specific locations. Successful sustainability processes and actors in cities have become vibrant research fields. However, geographical concepts have been widely neglected in transition research. We argue that what is needed is an explicit geographical research agenda that considers politics, power, and non-economic actors as drivers and resistant forces of changed practices. To overcome these challenges, bridging ideas of Transition Studies and strands of Economic Geography—notably Geographies of Innovation, Evolutionary Economic Geography, and Environmental Economic Geography—are highly valuable. Geographies of Innovation provide insights into technological innovation processes, including considerations of agency and institutional processes at different spatial scales, particularly at the regional level. Concepts of Evolutionary Economic Geography receive much attention for their consideration of temporal and spatial contextualisation of industrial and technological change. Scholars from Environmental Economic Geography have highlighted environmental and sustainability issues at the firm and industry level. We argue that combining these related concepts helps to identify and analyse the dynamic interplay between changed socio-technological practices, institutional processes and related driving and hindering actors in sustainability transitions.

This paper suggests three analytical foci for (urban) sustainability transition research: 
1. key pathways, directions, and interactions between technological and institutional-political and socio-cultural logics;

2. processes and practices of learning and resistance;

3. actors (driving and resistant) and their interests.

While these analytical foci are already pervasive in much of the current research on urban change, the interrelations between these factors are still not fully understood. Future research in the field of (urban) sustainability transitions, therefore, should focus more systematically on these complex interrelations. Moreover, a broader understanding of innovations, including not only technological change but also innovations in policy instruments or bottom-up initiatives by civil society groups seems to be necessary. There is increasing evidence that the interplay between specific policies, learning processes, and changed practices plays a decisive role in socio-technological change. Geographical concepts can help to identify and analyse the dynamics, directions, actors, processes of resistance and lock-in in urban transitions. The outcomes have implications for policy-makers and practitioners who should 'custom-tailor' and generate new pathways of governance and innovative practices. Apart from adapting blueprints of successful transition processes, decision-makers should also learn from unsuccessful urban transition pathways. The deep analysis of urban contexts, including local knowledge, actors, and existing sustainability paths should help to tailor new approaches for policy making.

Author Contributions: S.F. and B.B. conceived and designed the paper; S.F. wrote the paper.

Funding: This work was funded by the German Research Foundation (Grant number: BR 1678/12-1); and the National Research Fund Luxembourg (FNR) (Grant number: INTER_DFG/12-01/GreenRegio).

Acknowledgments: We would like to thank three anonymous reviewers for their valuable comments and suggestions.

Conflicts of Interest: The authors declare no conflict of interest.

\section{References}

1. Avelino, F.; Wittmayer, J. A Multi-Actor Perspective on Urban Sustainability Transitions. In Urban Sustainability Transitions. The Dynamics and Opportunities of Sustainability Transitions in Cities; Frantzeskaki, N., Castán Broto, V., Loorbach, D., Coenen, L., Eds.; Routledge: New York, NY, USA, 2017; pp. 272-284.

2. Bulkeley, H.; Castán Broto, V.; Maassen, A. Governing urban low carbon transition. In Cities and Low Carbon Transition; Bulkeley, H., Castán Broto, V., Hodson, M., Marvin, S., Eds.; Routledge: Abingdon, VA, USA, 2011.

3. Frantzeskaki, N.; Castán Broto, V.; Loorbach, D.; Coenen, L. Urban Sustainability Transitions; Routledge: New York, NY, USA, 2017.

4. WBGU. Humanity on the Move: Unlocking the Transformative Power of Cities; WBGU, German Advisory Council on Global Change: Berlin, Germany, 2016.

5. Coenen, L.; Hansen, T.; Rekers, J.V. Innovation Policy for Grand Challenges. An Economic Geography Perspective. Geogr. Compass 2015, 9, 483-496. [CrossRef]

6. Gibbs, D.; O'Neill, K. Future green economies and regional development: A research agenda. Reg. Stud. 2017, 51, 161-173. [CrossRef]

7. Murphy, J.T. Human geography and socio-technical transition studies: Promising intersections. Environ. Innov. Soc. Transit. 2015, 17, 73-91. [CrossRef]

8. Binz, C.; Truffer, B.; Coenen, L. Why space matters in technological innovation systems-Mapping global knowledge dynamics of membrane bioreactor technology. Res. Policy 2014, 43, 138-155. [CrossRef]

9. Coenen, L.; Truffer, B. Places and spaces of sustainability transitions: Geographical contributions to an emerging research and policy field. Eur. Plan. Stud. 2012, 20, 367-374. [CrossRef]

10. Geels, F.W. A socio-technical analysis of low-carbon transitions: Introducing the multi-level perspective into transport studies. J. Transp. Geogr. 2012, 24, 471-482. [CrossRef]

11. Truffer, B.; Murphy, J.T.; Raven, R. The geography of sustainability transitions: Contours of an emerging theme. Environ. Innov. Soc. Transit. 2015, 17, 63-72. [CrossRef]

12. Hansen, T.; Coenen, L. The geography of sustainability transitions: Review, synthesis and reflections on an emergent research field. Environ. Innov. Soc. Transit. 2015, 17, 92-109. [CrossRef] 
13. Truffer, B.; Coenen, L. Environmental innovation and sustainability transitions in regional studies. Reg. Stud. 2012, 46, 1-21. [CrossRef]

14. Geels, F.W. Technological Transitions as Evolutionary Reconfiguration Processes: A Multi-level Perspective and a Case-study. Res. Policy 2002, 31, 1257-1274. [CrossRef]

15. Boschma, R.; Coenen, L.; Frenken, K.; Truffer, B. Towards a theory of regional diversification: Combining insights from Evolutionary Economic Geography and Transition Studies. Reg. Stud. 2017, 51, 31-45. [CrossRef]

16. Truffer, B. Society, technology, and region: Contributions from the social study of technology to economic geography. Environ. Plan. A 2008, 40, 966-985. [CrossRef]

17. Jones, M. Phase space: Geography, relational thinking, and beyond. Prog. Hum. Geogr. 2009, 33, 487-506. [CrossRef]

18. Jones, A.; Murphy, J.T. Theorizing practice in economic geography: Foundations, challenges, and possibilities. Prog. Hum. Geogr. 2011, 35, 366-392. [CrossRef]

19. Faller, F. A practice approach to study the spatial dimensions of the energy transition. Environ. Innov. Soc. Transit. 2016, 19, 85-95. [CrossRef]

20. Faller, F.; Schulz, C. Sustainable practices of the energy transition-Evidence from the biogas and building industries in Luxembourg. Appl. Geogr. 2018, 90, 331-338. [CrossRef]

21. Fastenrath, S.; Braun, B. Sustainability transition pathways in the building sector: Energy-efficient building in Freiburg (Germany). Appl. Geogr. 2018, 90, 339-349. [CrossRef]

22. Dosi, G. Technological Paradigms and Technological Trajectories: A Suggested Interpretation of the Determinants and Directions of Technical Change. Res. Policy 1982, 11, 147-162. [CrossRef]

23. Nelson, R.; Winter, S. An Evolutionary Theory of Economic Change; Belknap Press of Harvard University Press: Cambridge, MA, USA, 1982.

24. Norgaard, R. Coevolutionary Development Potential. Land Econ. 1984, 60, 160-173. [CrossRef]

25. Lloyd, P.E.; Dicken, P. Location in Space. A Theoretical Approach to Economic Geography, 2nd ed.; Harper \& Row: London, UK, 1977.

26. Giddens, A. The Constitution of Society: Outline of the Theory of Structuration; University of California Press: Berkeley, CA, USA, 1984.

27. Granovetter, M. Economic action and social structure: The problem of embeddedness. Am. J. Sociol. 1985, 91, 481-510. [CrossRef]

28. Dosi, G.; Freeman, C.; Nelson, R.; Silverberg, G.; Soete, L. Technological Change and Economic Theory; Pinter Publishers: London, UK, 1988.

29. Freeman, C. The National System of Innovation in Historical Perspective. Camb. J. Econ. 1995, 19, 5-24.

30. Lundvall, B.A. National Systems of Innovation: Towards a Theory of Innovation and Interactive Learning; Pinter Publishers: London, UK, 1992.

31. Kemp, R. Technology and the Transition to Environmental Sustainability: The Problem of Technological Regime Shifts. Futures 1994, 26, 1023-1046. [CrossRef]

32. Kemp, R.; Schot, J.; Hoogma, R. Regime Shifts to Sustainability through Processes of Niche Formation: The Approach of Strategic Niche Management. Technol. Anal. Strat. Manag. 1998, 10, 175-198. [CrossRef]

33. Rip, A.; Kemp, R. Technological Change. In Human Choice and Climate Change; Rayner, S., Malone, E.L., Eds.; Battelle Press: Columbus, OH, USA, 1998; Volume 2, pp. 327-399.

34. Grin, J.; Rotmans, J.; Schot, J. Transitions to Sustainable Development: New Directions in the Study of Long Term Transformative Change; Routledge: New York, NY, USA, 2010.

35. Geels, F.W. The Dynamics of Transitions in Socio-technical Systems: A Multi-level Analysis of the Transition Pathway from Horse-drawn Carriages to Automobiles (1860-1930). Technol. Anal. Strat. Manag. 2005, 17, 445-476. [CrossRef]

36. Geels, F.W. The hygienic transition from cesspools to sewer systems (1840-1930): The dynamics of regime transformation. Res. Policy 2006, 35, 1069-1082. [CrossRef]

37. Kemp, R.; Rotmans, J. Managing the transition to sustainable mobility. In System Innovation and the Transition to Sustainability: Theory, Evidence and Policy; Elzen, B., Geels, F.W., Green, K., Eds.; Edward Elgar Publishing Ltd.: Cheltenham, UK, 2004; pp. 137-167.

38. Smith, A. Translating sustainabilities between green niches and socio-technical regimes. Technol. Anal. Strat. Manag. 2007, 19, 427-450. [CrossRef] 
39. Smith, A.; Stirling, A.; Berkhout, F. The governance of sustainable socio-technical transitions. Res. Policy 2005, 34, 1491-1510. [CrossRef]

40. Markard, J.; Raven, R.; Truffer, B. Sustainability transitions: An emerging field of research and its prospects. Res. Policy 2012, 41, 955-967. [CrossRef]

41. Geels, F.W. The Multi-level Perspective on Sustainability Transitions: Responses to Seven Criticisms. Environ. Innov. Soc. Transit. 2011, 1, 24-40. [CrossRef]

42. Smith, A.; Voß, J.P.; Grin, J. Innovation studies and sustainability transitions: The allure of the multi-level perspective and its challenges. Res. Policy 2010, 39, 435-448. [CrossRef]

43. Shove, E.; Walker, G. CAUTION! Transitions ahead: Politics, practice, and sustainable transition management. Environ. Plan. A 2007, 39, 763-770. [CrossRef]

44. Cooke, P. Regional innovation systems: Development opportunities from the 'green turn'. Technol. Anal. Strat. Manag. 2010, 22, 831-844. [CrossRef]

45. Smith, A.; Raven, R. What is protective space? Reconsidering niches in transitions to sustainability. Res. Policy 2012, 41, 1025-1036. [CrossRef]

46. Geels, F.W. Ontologies, socio-technical transitions (to sustainability), and the multi-level perspective. Res. Policy 2010, 39, 495-510. [CrossRef]

47. Fuenfschilling, L.; Truffer, B. The structuration of socio-technical regimes-Conceptual foundations from institutional theory. Res. Policy 2014, 43, 772-791. [CrossRef]

48. Maassen, A. Heterogeneity of Lock-In and the Role of Strategic Technological Interventions in Urban Infrastructural Transformations. Eur. Plan. Stud. 2012, 20, 441-460. [CrossRef]

49. Markard, J.; Truffer, B. Technological Innovation Systems and the Multi-level Perspective: Towards an Integrated Framework. Res. Policy 2008, 37, 596-615. [CrossRef]

50. Geels, F.W. Regime Resistance against Low-Carbon Transitions: Introducing Politics and Power into the Multi-Level Perspective. Theory Cult. Soc. 2014, 31, 21-40. [CrossRef]

51. WBGU. World in Transition-A Social Contract for Sustainability; German Advisory Council on Global Change (WBGU): Berlin, Germany, 2011.

52. Bathelt, H.; Glückler, J. Wirtschaftsgeographie; Eugen Ulmer KG: Stuttgart, Germany, 2012.

53. Boschma, R.; Martin, R. The aims and scope of evolutionary economic geography. In The Handbook of Evolutionary Economic Geography; Boschma, R., Martin, R., Eds.; Edward Elgar Publishing: Cheltenham, UK, 2010; pp. 3-39.

54. Asheim, B.T.; Gertler, M.S. The Geography of Innovation-Regional Innovation Systems. In The Oxford Handbook of Innovation; Oxford University Press: Oxford, UK, 2005; pp. 291-317.

55. Braun, B. Competitive and Green? Determinants of Successful Environmental Management in the Manufacturing Sector. In Knowledge, Industry and Environment: Institutions and Innovation in Territorial Perspective; Hayter, R., Le Heron, R., Eds.; Ashgate: Aldershot, UK, 2002.

56. Braun, B.; Schulz, C.; Soyez, D. Konzepte und Leitthemen einer ökologischen Modernisierung der Wirtschaftsgeographie. Zeitschrift fur Wirtschaftsgeographie 2003, 47, 213-248. [CrossRef]

57. Patchell, J.; Hayter, R. Environmental and Evolutionary Economic Geography: Time for Eeg(2)? Geogr. Ann. Ser. B Hum. Geogr. 2013, 95, 111-130. [CrossRef]

58. Soyez, D.; Schulz, C. Facets of an emerging Environmental Economic Geography (EEG). Geoforum 2008, 39, 17-19. [CrossRef]

59. Amin, A. An institutionalist perspective on regional economic development. Int. J. Urban Reg. Res. 1999, 23, 365-387. [CrossRef]

60. Morgan, K. The Learning Region: Institutions, Innovation and Regional Renewal. Reg. Stud. 1997, 31, 491-503. [CrossRef]

61. Storper, M. The Regional World: Territorial Development in a Global Economy; Guilford Press: New York, NY, USA, 1997.

62. Storper, M.; Scott, A.J. The Wealth of Regions: Market Forces and Policy Imperatives in Local and Global Context. Futures 1995, 27, 505-526. [CrossRef]

63. Hassink, R.; Shin, D.-H. Guest Editorial. Environ. Plan. A 2005, 37, 571-580. [CrossRef]

64. Amin, A.; Thrift, N. What Kind of Economic Theory for what Kind of Economic Geography? Antipode 2000, 32, 4-9. [CrossRef] 
65. Boschma, R.A.; Lambooy, J.G. Evolutionary economics and economic geography. J. Evol. Econ. 1999, 9, 411-429. [CrossRef]

66. Maskell, P.; Malmberg, A. Localised learning and industrial competitiveness. Camb. J. Econ. 1999, 23, 167-185. [CrossRef]

67. Camagni, R.P. The concept of innovative milieu and its relevance for public policies in European lagging regions. Pap. Reg. Sci. 1995, 74, 317-340. [CrossRef]

68. Porter, M.E. The Competitive Advantage of Nations; Harvard Business Review: Cambridge, MA, USA, 1990.

69. Martin, R. Institutional Approaches in Economic Geography. In A Companion to Economic Geography; Barnes, T.J., Sheppard, E., Eds.; Blackwell Publishing Ltd.: Oxford, UK, 2000; pp. 77-94.

70. Bathelt, H.; Malmberg, A.; Maskell, P. Clusters and knowledge: Local buzz, global pipelines and the process of knowledge creation. Prog. Hum. Geogr. 2004, 28, 31-56. [CrossRef]

71. Revilla Diez, J.; Kiese, M. Regional Innovation Systems. In International Encyclopedia of Human Geography; Kitchin, R., Thrift, N., Eds.; Elsevier: Oxford, UK, 2009; pp. 246-251.

72. Nelson, R.R. National Innovation Systems: A Retrospective on a Study. Ind. Corp. Chang. 1992, 1, 347-374. [CrossRef]

73. Asheim, B.T.; Isaksen, A. Regional Innovation Systems: The Integration of Local 'Sticky' and Global 'Ubiquitous' Knowledge. J. Technol. Transf. 2002, 27, 77-86. [CrossRef]

74. Asheim, B.T.; Coenen, L. Knowledge bases and regional innovation systems: Comparing Nordic clusters. Res. Policy 2005, 34, 1173-1190. [CrossRef]

75. Cooke, P. Regional Innovation Systems, Clusters, and the Knowledge Economy. Ind. Corp. Change 2001, 10, 945-974. [CrossRef]

76. Asheim, B.T.; Smith, H.L. Regional Innovation Systems: Theory, Empirics and Policy. Reg. Stud. 2011, 45, 875-891. [CrossRef]

77. Cooke, P.; Gomez Uranga, M.; Etxebarria, G. Regional innovation systems: Institutional and organisational dimensions. Res. Policy 1997, 26, 475-491. [CrossRef]

78. Cooke, P. Regional Innovation Systems, Clean Technology \& Jacobian Cluster-Platform Policies. Reg. Sci. Policy Pract. 2008, 1, 23-45.

79. Braun, B. Unternehmen Zwischen Ökologischen und Ökonomischen Zielen. Konzepte, Akteure und Chancen des Umweltmanagements aus Wirtschaftsgeographischer Sicht; LIT: Münster, Germany, 2003.

80. Braun, B. What makes environmental management systems successful? An empirical study on German manufacturing sector. In Managing the Business Case for Sustainability. The Integration of Social, Environmental and Economic Performance; Schaltegger, S., Wagner, M., Eds.; Greanleaf: Sheffield, UK, 2005; pp. 589-614.

81. Gibbs, D.; Healey, M. Industrial geography and the environment. Appl. Geogr. 1997, 17, 193-201. [CrossRef]

82. Gibbs, D. Prospects for an Environmental Economic Geography: Linking Ecological Modernization and Regulationist Approaches. Econ. Geogr. 2006, 82, 193-215. [CrossRef]

83. Hayter, R.; Le Heron, R. (Eds.) Knowledge, Industry and Environmental. Institutions and Innovation in Territorial Perspective; Ashgate Publishing Limited: Aldershot, UK, 2002.

84. Hayter, R. Environmental Economic Geography. Geogr. Compass 2008, 2, 831-850. [CrossRef]

85. Schulz, C. Environmental Service-providers, Knowledge Transfer, and the Greening of Industry. In Knowledge, Industry and Environmental. Institutions and Innovation in Territorial Perspective; Hayter, R., Le Heron, R., Eds.; Ashgate Publishing Limited: Aldershot, UK, 2002; pp. 209-226.

86. Schulz, C. Agenten des Wandels? Unternehmensbezogene Dienstleister im Industriellen Produktionssystem; Oekom: München, Germany, 2005.

87. Soyez, D. Environmental Knowledge, the Power of Framing and Industrial Change. In Knowledge, Industry and Environmental. Institutions and Innovation in Territorial Perspective; Hayter, R., Le Heron, R., Eds.; Ashgate Publishing Limited: Aldershot, UK, 2002; pp. 187-208.

88. Taylor, M. Industrialisation, Enterprise Power, and Environmental Change: An Exploration of Concepts. Environ. Plan. A 1996, 28, 1035-1051. [CrossRef]

89. Hayter, R.; Le Heron, R. Conclusions: Institutions and Innovation in Territorial Perspective. In Knowledge, Industry and Environmental. Institutions and Innovation in Territorial Perspective; Hayter, R., Le Heron, R., Eds.; Ashgate Publishing Limited: Aldershot, UK, 2002; pp. 399-409.

90. Braun, B.; Oßenbrügge, J.; Schulz, C. Environmental economic geography and environmental inequality: Challenges and new research prospects. Zeitschrift für Wirtschaftsgeographie 2018, 62, 120-134. [CrossRef] 
91. Strambach, S.; Pflitsch, G. Micro-dynamics in regional transition paths to sustainability-Insights from the Augsburg region. Appl. Geogr. 2018, 90, 296-307. [CrossRef]

92. Aoyama, Y.; Murphy, J.T.; Hanson, S. (Eds.) Sustainable Development. In Key Concepts in Economic Geography; Sage Publications Ltd.: London, UK, 2011; pp. 217-263.

93. Garud, R.; Karnoe, P. Path creation as a process of mindful deviation. In Path Dependence and Creation; Garud, R., Karnoe, P., Eds.; Lawrence Erlbaum Associates Publishers: Mahwah, NJ, USA, 2011; pp. 1-38.

94. Simmie, J. Path dependence and new technological path creation in the economic landscape. In Re-Framing Regional Development_Evolution, Innovation and Transition; Cooke, P., Ed.; Routledge: Oxon, NY, USA, 2013; pp. 164-185.

95. Boschma, R.; Frenken, K. Why is economic geography not an evolutionary science? Towards an evolutionary economic geography. J. Econ. Geogr. 2006, 6, 273-302. [CrossRef]

96. Boschma, R.; Frenken, K. The emerging empirics of evolutionary economic geography. J. Econ. Geogr. 2011, 11, 295-307. [CrossRef]

97. Martin, R.; Sunley, P. The place of path dependence in an evolutionary perspective on the economic landscape. In The Handbook of Evolutionary Economic Geography; Boschma, R., Martin, R., Eds.; Edward Elgar Publishing: Cheltenham, UK, 2010; pp. 62-92.

98. Boschma, R. Proximity and Innovation: A Critical Assessment. Reg. Stud. 2005, 39, 61-74. [CrossRef]

99. Grabher, G. The Embedded Firm on the Socioeconomics of Industrial Networks; Routledge: London, UK, 1993.

100. Hassink, R. How to unlock regional economies from path dependency? From learning region to learning cluster. Eur. Plan. Stud. 2015, 13, 521-535. [CrossRef]

101. Hassink, R. Locked in decline? On the role of regional lock-ins in old industrial areas. In The Handbook of Evolutionary Economic Geography; Boschma, R., Martin, R., Eds.; Edward Elgar Publishing: Cheltenham, UK, 2010; pp. 450-468.

102. Strambach, S.; Halkier, H. Reconceptualising Change. Path Dependency, Path Plasticity and Knowledge Combination. Zeitschrift fur Wirtschaftsgeographie 2013, 57, 1-14. [CrossRef]

103. Martin, R.; Sunley, P. Path dependence and regional economic evolution. J. Econ. Geogr. 2006, 6, 395-437. [CrossRef]

104. Garud, R.; Kumaraswamy, A.; Karnøe, P. Path Dependence or Path Creation? J. Manag. Stud. 2010, 47, 760-774. [CrossRef]

105. Pike, A.; Birch, K.; Cumbers, A.; MacKinnon, D.; McMaster, R. A Geographical Political Economy of Evolution in Economic Geography. Econ. Geogr. 2009, 85, 175-182. [CrossRef]

106. Valderrama Pineda, A.F.; Braagaard Harders, A.K.; Elle, M. Mediators Acting in Urban Transition Processes. Carlsberg City District and Cycle Superhighways. In Urban Sustainability Transitions. The Dynamics and Opportunities of Sustainability Transitions in Cities; Frantzeskaki, N., Castán Broto, V., Loorbach, D., Coenen, L., Eds.; Routledge: New York, NY, USA, 2017.

107. Scott, A.J.; Storper, M. The Nature of Cities: The Scope and Limits of Urban Theory. Int. J. Urban Reg. Res. 2015, 39, 1-15. [CrossRef]

108. Cooke, P. Transition regions: Regional-national eco-innovation systems and strategies. Prog. Plan. 2011, 76, 105-146. [CrossRef]

109. Dewald, U.; Fromhold-Eisebith, M. Trajectories of sustainability transitions in scale-transcending innovation systems: The case of photovoltaics. Environ. Innov. Soc. Transit. 2015, 17, 110-125. [CrossRef]

110. Affolderbach, J.; Schulz, C. Mobile transitions: Exploring synergies for urban sustainability research. Urban Stud. 2016, 53, 1942-1957. [CrossRef]

111. McCann, E. Urban Policy Mobilities and Global Circuits of Knowledge: Toward a Research Agenda. Ann. Assoc. Am. Geogr. 2011, 101, 107-130. [CrossRef]

112. McCann, E.; Ward, K. Mobile Urbanism: Cities and Policymaking in the Global Age; University of Minnesota Press: Minneapolis, MN, USA, 2011.

113. Peck, J.; Theodor, N. Mobilizing policy: Models, methods, and mutations. Geoforum 2010, 41, 169-174. [CrossRef]

114. Gorissen, L.; Spira, F.; Meynaerts, E.; Valkering, P.; Frantzeskaki, N. Moving towards systemic change? Investigating acceleration dynamics of urban sustainability transitions in the Belgian City of Genk. J. Clean. Prod. 2018, 173, 171-185. [CrossRef] 
115. Hodson, M.; Geels, F.; McMeekin, A. Reconfiguring Urban Sustainability Transitions, Analysing Multiplicity. Sustainability 2017, 9. [CrossRef]

116. Fastenrath, S.; Braun, B. Ambivalent urban sustainability transitions: Insights from Brisbane's building sector. J. Clean. Prod. 2018, 176, 581-589. [CrossRef]

117. Geels, F.; Schot, J. Typology of sociotechnical transition pathways. Res. Policy 2007, 36, 399-417. [CrossRef]

118. Turnheim, B.; Berkhout, F.; Geels, F.; Hof, A.; McMeekin, A.; Nykvist, B.; van Vuuren, D. Evaluating sustainability transitions pathways: Bridging analytical approaches to address governance challenges. Glob. Environ. Chang. 2015, 35, 239-253. [CrossRef]

119. Coutard, O.; Rutherford, J. Energy transition and city-region planning: Understanding the spatial politics of systemic change. Technol. Anal. Strat. Manag. 2010, 22, 711-727. [CrossRef]

120. Nightingale, A.J. Power and politics in climate change adaptation efforts: Struggles over authority and recognition in the context of political instability. Geoforum 2017, 84, 11-20. [CrossRef]

121. Van Assche, K.; Beunen, R.; Duineveld, M. Evolutionary Governance Theory. An Introduction; Springer International Publishing: Heidelberg, Germany, 2014.

122. Burch, S. The Governance of Transformative Change: Tracing the Pathway of the Sustainability Transition in Vancouver, Canada. In Urban Sustainability Transitions. The Dynamics and Opportunities of Sustainability Transitions in Cities; Frantzeskaki, N., Castán Broto, V., Loorbach, D., Coenen, L., Eds.; Routledge: New York, NY, USA, 2017; pp. 50-64.

123. Brown, R.; Farrelly, M.; Loorbach, D. Actors working the institutions in sustainability transitions: The case of Melbourne's stormwater management. Glob. Environ. Chang. 2013, 23, 701-718. [CrossRef]

124. Davies, A.R.; Mullin, S.J. Greening the economy: Interrogating sustainability innovations beyond the mainstream. J. Econ. Geogr. 2011, 11, 793-816. [CrossRef]

125. Malmberg, A.; Maskell, P. An evolutionary approach to localized learning and spatial clustering. In The Handbook of Evolutionary Economic Geography; Boschma, R., Martin, R., Eds.; Edward Elgar Publishing: Cheltenham, UK, 2010; pp. 391-405.

126. Shove, E.; Walker, G. Governing transitions in the sustainability of everyday life. Res. Policy 2010, 39, 471-476. [CrossRef]

127. Hargreaves, T.; Longhurst, N.; Seyfang, G. Up, down, round and round: Connecting regimes and practices in innovation for sustainability. Environ. Plan. A 2013, 45, 402-420. [CrossRef]

128. Seyfang, G.; Longhurst, N. What influences the diffusion of grassroots innovations for sustainability? Investigating community currency niches. Technol. Anal. Strat. Manag. 2016, 28, 1-23. [CrossRef]

129. Smedby, N.; Neij, L. Experiences in urban governance for sustainability: The Constructive Dialogue in Swedish municipalities. J. Clean. Prod. 2013, 50, 148-158. [CrossRef]

130. Corvellec, H.; Zapata Campos, M.J.; Zapata, P. Infrastructures, lock-in, and sustainable urban development: The case of waste incineration in the Göteborg Metropolitan Area. J. Clean. Prod. 2013, 50, 32-39. [CrossRef]

131. De Gooyert, V.; Rouwette, E.; van Kranenburg, H.; Freeman, E.; van Breen, H. Sustainability transition dynamics: Towards overcoming policy resistance. Technol. Forecast. Soc. Chang. 2016, 111, 135-145. [CrossRef]

132. Grin, J.; Frantzeskaki, N.; Castán Broto, V.; Coenen, L. Sustainability Transitions and the City. Linking to Transition Studies and Looking Forward. In Urban Sustainability Transitions. The Dynamics and Opportunities of Sustainability Transitions in Cities; Frantzeskaki, N., Castán Broto, V., Loorbach, D., Coenen, L., Eds.; Routledge: New York, NY, USA, 2017.

133. Wolfram, M. Cities shaping grassroots niches for sustainability transitions: Conceptual reflections and an exploratory case study. J. Clean. Prod. 2016. [CrossRef]

134. Coenen, L.; Raven, R.; Verbong, G. Local niche experimentation in energy transitions: A theoretical and empirical exploration of proximity advantages and disadvantages. Technol. Soc. 2010, 32, 295-302. [CrossRef]

(C) 2018 by the authors. Licensee MDPI, Basel, Switzerland. This article is an open access article distributed under the terms and conditions of the Creative Commons Attribution (CC BY) license (http:/ / creativecommons.org/licenses/by/4.0/). 